\title{
MEDIATING ROLE OF CONSUMER INVOLVEMENT BETWEEN CELEBRITY ENDORSEMENT AND CONSUMER EVALUATION: COMPARATIVE STUDY OF HIGH AND LOW INVOLVEMENT PRODUCT
}

\author{
Nilesh Arora1, Sanjeev Prashar ${ }^{2}$, Chandan Parsad ${ }^{3 *}$, and T. Sai Vijay \\ ${ }^{1}$ Chandigarh University, Mohali 140413, Punjab, India \\ ${ }^{2}$ Indian Institute of Management (IIM) Raipur, Old Dhamtari Road, \\ Sejbahar, Raipur 492015, Chhattisgarh, India \\ ${ }^{3}$ Rajagiri Business School, Rajagiri Valley P. O., Kakkanad, \\ Kochi, Kerala 682039, India \\ ${ }^{4}$ Indian Institute of Management Ranchi, Suchana Bhawan, \\ 5th Floor, Audrey House Campus, Ranchi 834008, India \\ *Corresponding author: chandanparsad@gmail.com
}

Published online: 30 December 2019

To cite this article: Arora, N., Prashar, S., Parsad, C., and Vijay, T.S. (2019). Mediating role of consumer involvement between celebrity endorsement and consumer evaluation: Comparative study of high and low involvement product. Asian Academy of Management Journal, 24(2), 113-142. https://doi.org/10.21315/aamj2019.24.2.6

To link to this article: https://doi.org/10.21315/aamj2019.24.2.6

\begin{abstract}
Celebrity endorsement has been an important area of study from the perspectives of marketers as well as consumers. This research aims at developing and testing a model of celebrity endorsement with celebrity-product congruence and attractiveness as predictor variables, with consumer involvement affecting a consumer assessment of the brand and purchase intention. The research has been guided by current attention being given to the significance of celebrities for endorsing products. However, the same has not been duly explored in the context of celebrity endorsement, with consumer involvement as a mediating variable, and further its impact on consumers' evaluation. The present research discusses the relationship effect of celebrity endorsement on consumers' evaluation of the communication done through the celebrity endorsing the brand. The study highlights mediating role of consumer involvement for both high and low involvement products in formation of attitude towards advertisement and buying intention. Using mall intercept method, the data was collected from 246 respondents. Structural equation modelling was used for analysing the data using AMOS 22.0. The results indicate that consumer responses
\end{abstract}

(C) Asian Academy of Management and Penerbit Universiti Sains Malaysia, 2019. This work is licensed under the terms of the Creative Commons Attribution (CC BY) (http://creativecommons. org/licenses/by/4.0/). 
are maximised when endorser attractiveness and consumer involvement interact with each other. Also, it is observed that consumer involvement has maximum impact on attitude toward advertisement. The paper closes with theoretical and managerial implication.

Keywords: celebrity endorsement, celebrity attractiveness, celebrity-product congruence, consumer involvement, attitude towards advertisement

\section{INTRODUCTION}

Celebrity endorsement is the most widely used method for brand advertising and reinforcement (McCracken, 1989), and its acceptance is constantly rising across the world, mainly in the United States and China (Hung et al., 2011). Though the use of celebrities in marketing communication does not necessarily assure sales growth, however, it can attract attention to promotional communication and shape a more favourable view of the brand (Erdogan et al., 2001; Sonwalkar et al., 2011). According to studies like Amos et al. (2008) and Freiden (1984), celebrities endorsing the brands create advantageous behavioural responses among the end users. Marketers use celebrities to endorse brands with and intention to draw consumer attention and affect consumer attitudes and purchase intentions (Munnukka et al., 2016; Pradhan et al., 2016; Yang, 2018; Zhou \& Whitla, 2013). In the complex marketing situations, where differentiating products on technology platform is extremely difficult, a celebrity plays an important role in advertising, and creating and enhancing brand image and brand equity.

Bradic (2015) noted that sales can instantaneously increase by four percent with just one endorsement. According to Ad Age (2010), the moment the news is made public about an endorsement contract between a celebrity and a brand, brand's stock might rise by 0.25 points. This symbolises an increase in perceived authenticity due to a celebrity's endorsement, even though the product remains the same. Moreover, well researched endorsements generate equity for advertised brand as well as the endorser (Seno \& Lukas, 2007).

Endorsement literature has been quite rich in terms of studies focusing on the factors affecting the choice of the celebrity for endorsing a brand, influence of celebrity-product congruence on buying behaviour, and credibility of endorsers (Lee \& Koo 2015; Mishra et al., 2015). Another set of celebrity endorsement studies, tagged as "match-up hypothesis," has deciphered a congruence between a celebrity endorser and the brand (product) being endorsed (Kahle \& Homer, 1985; Kamins, 1990). Most of these endorsement studies pivoted on factors salient to an effective celebrity endorser. These include attractiveness of an endorser (McGuire, 1985), likeability (Erdogen, 1999), credibility, believability, and 
expertise (Ohanian, 1990), and familiarity (Kamins, 1990; and Misra and Beatty, 1990). Also, Branchik and Chowdhury (2017) support that celebrity endorser's talent; attractiveness, credibility, and success have significant impact on the endorsed products and services. A gamut of research works has also examined the congruence between the image of the celebrity endorsing a brand (product) and the image of the brand (product) or organisation (Kamins \& Gupta, 1994; Lynch \& Schuler, 1994; Till \& Busler, 1998). Thus, most of the studies in this area have been limited to the endorser credibility and match-up hypothesis. These two constructs have received great attention for several years because of their positive effects on an advertising outcome.

In addition, even though quite a few researches have also been conducted on celebrity attractiveness and their impact on consumer attitude, till date, these two areas of research have not been intervened with the level of consumer involvement. Consumer involvement has been underrated in endorsement literature as not many researchers have considered it to be a prime construct in their studies. Some researchers have brought consumer involvement into the celebrity endorsement studies. Schaefer and Keillor (1997) posited that higher level of consumer involvement fetches improved product-endorser congruence effect, besides bringing better brand approach evaluation.

To bridge this gap in the existing literature, the present study empirically tests a model incorporating celebrity-product congruence and celebrity endorser attractiveness as predictors and their impact on consumer evaluation of the brand. This is measured through the three constructs - attitude of the consumer towards the advertisement, towards the brand, and the purchase intentions, as the criterion variables. Between these constructs, consumer involvement has been incorporated as a mediating variable. For this purpose, two models were examined by taking a smartphone (brand Vivo), a high involvement and beauty soap (brand Lux), a low involvement product respectively. The models were examined empirically using the data collected from a representative sample of Indian consumers.

\section{Research Objectives}

Endorsement studies conducted during the last few decades present majorly two main areas of research as match-up hypotheses and credibility in different contexts. However, there is a vast gap in the existing literature on endorsement. The consumer aspect has not much been explored in the literature. The proposed research explores whether a consumers' involvement in the purchase decision has any intervening effect on consumer's attitude towards the advertisement, attitude towards the brand, and purchase intentions. Primarily, this study compares 
the influence of level of consumers' involvement on their attitude towards advertisement, brand and purchase intention, in the presence of two antecedents of celebrity endorsement. Consumer involvement, for the present research has been studied with two categories of product priced at two different levels - smartphone and beauty soap. The smartphone purchase decision is a high involvement product, where a buyer must spend INR 30,000, while the beauty soap is a low involvement product, with a price of INR 50 .

Thus, the questions the researchers try to answer through this study are:

RQ 1:Do endorser-product congruence and endorser attractiveness affect a consumer's involvement?

RQ 2:Does consumer involvement act as a mediator between the celebrity endorsement factors and the consumers' attitude towards an advertisement, a brand and purchase intention for a product endorsed by a celebrity?

The rest of the paper has been arranged as follows. The subsequent section discusses the review of literature on celebrity endorsement, attractiveness, celebrity-product congruence, and consumer involvement. Next, research hypotheses are detailed based on the literature review. Later, discussions on the research methodology used and the outcomes from hypotheses testing are addressed. Theoretical and managerial implications of the study are discussed in the concluding section followed by the limitations and the scope for future study.

\section{THEORETICAL FRAMEWORK}

The research found its basis from two major theories. One is "meaning transfer theory" (McCracken, 1989), where the celebrity's image, status, and attractiveness transfer to the brand through the endorsement and the other is elaboration likelihood model (ELM). The model explains different ways of understanding the effects of stimuli on attitude change (Petty \& Cacioppo, 1986). ELM posits two routes for persuasion to happen - central route and the peripheral route. The central route to persuasion is a promotional approach that maintains that consumers with high involvement are best reached and convinced through advertisements focused on the product's attributes. The peripheral route to persuasion is a promotional approach maintaining that consumers with low involvement can be best convinced by the advertisement's visual aspects rather than its instructive copy. The central route to persuasion supports the right benefits of arguments wherein a person thinks 
logically and rationally about information cue. On the other hand, the peripheral route to persuasion includes simple cues where the individual is unrelated to the rationality or the logical aspect of the stimuli and thus require less cognitive efforts (Wang et al., 2019). The model has been extended to various spheres like product advertising, social media (Hur et al., 2017), information technology (Bhattacherjee \& Sanford, 2006), health care (Flynn et al., 2011), and online shopping (Yang, 2015). ELM (Petty \& Cacioppo, 1986) specifies that Brand Purchase Intention is a function of Brand Attitude. The role of the celebrity in an advertisement under different product involvement conditions is an area that needs attention. This can be elucidated in the milieu of the ELM. While the ELM clarifies that tangential cues are more vital than issue-related discussions under low product involvement conditions, certain researchers (Petty et al., 1983) have argued that the opposite can be true under high product involvement conditions.

\section{Celebrity Endorsement}

Celebrity endorsement is a form of marketing communication used by brand managers that uses a famous personality from sports, entertainment, education, fashion, or any other industry using their social status or their reputation to help endorse a product, service, or an idea. Often celebrities are used by companies in marketing communication and promotion activities to endorse, or to give testimony (Erdogan, 1999). Atkin and Block (1983) posited that celebrity endorsement is effective in changing consumers' mindset in favour of the brands, impacting the believability and reliability of advertisements positively and influencing consumers' purchase intentions. As per Misra and Beatty (1990), endorsements enhance brand recall and recognition, change the negative attitude towards the brand, and establish the credibility. According to Amos et al. (2008), advertisements endorsed by celebrities command high likeability among consumers, resulting in companies splurging huge sums to sign up celebrities to support their brands (Lee \& Thorson, 2008).

Endorsement by a celebrity reinforces the brand, allocates the brand with needed brand image attributes, positions the brand positively, renews the image of the brand, makes a brand well known in the society, draws the attention, enhances brand awareness; encourages consumers to buy and creates value for both the advertised brand and endorser (Amos et al., 2008; Erdogan et al., 2001; Kaikati, 1987; Seno \& Lukas, 2007; Sonwalkar et al., 2011).

According to Belch and Belch, (2001), celebrities create interest and attention to advertisement, termed as "stopping power," because of their attractiveness and likeability (Dyson \& Turco, 1998), and as they personify symbolic connotations 
(Schenk \& Holman, 1980; O'Guinn et al., 1989; Stern, 1988). The cool, lively and energised personality of a celebrity may lead to emotional attachment with the brand (Srivastava \& Sharma, 2016). According to Balakrishnan and Kumar (2011), there is an enormous impact of celebrity endorsements on Indian consumers as celebrities have huge fan following and these consumers consider them as their role models.

\section{Celebrity-Product Congruence}

Marketing domains like branding, marketing communication, brand extension, endorsements, sponsorships, etc., use the term match-up or congruence very frequently. According to Fleck and Quester (2007), match-up is the congruence between a brand and a celebrity or another brand or product class, or an occasion. Misra and Beatty (1990) defined congruence in celebrity endorsement as "the highly relevant characteristics of the spokesperson are consistent with the highly relevant attributes of the brand" (p. 161). The literature on a match-up or fitment in the field of celebrity endorsements has been categorised into three major classes depending upon the stimuli used in the fitment - attractiveness (Liu et al., 2007), expertise (Lee \& Thorson, 2008; Till \& Busler, 2000), and image (Kirmani \& Shiv, 1998). The compatibility between the celebrity and the product plays an important role in generating positive outcome in terms of essential marketing parameters like brand recall, attitude towards the advertisement, and brand assessments (Byrne et al., 2003; McCormick, 2016).

\section{Consumer Involvement}

Consumer involvement in buying refers to consumers' concern about certain purchases. Consumer involvement is defined as the interest, passion, and the fondness of a consumer for the particular product category (Goldsmith \& Emmert, 1991). Involvement is echoed by consumers' nosiness in using and disposing of products, services or ideas (Mowen, 1995). High involvement purchase decisionmaking involves the consumer spending extra time and effort on deliberation and information collection aimed at making more rational buying decision. On the other hand, very less time, effort, and money are invested during pre-purchase stage in case of low-involvement purchase decision-making. MacKenzie and Lutz (1989) observed that consumer involvement plays a significant role in consumer attitude and behaviour. Studies by MacInnis et al. (1991), and Janssens and De Pelsmacker (2005) reveal that consumers who show a high level of involvement in a buying decision represent a better quality and quantity of perception. 
As per Zaichkowsky (1985), consumers show diverse extent of involvement levels (either high or low) depending upon the product type they are buying. It has been observed that with increasing level of consumer's involvement in the product, the impact of the celebrity on buying decisions lessens (Kahle et al., 1980; Kahle \& Timmer, 1983). Similarly, celebrity's influence is heightened as the consumer's level of involvement in the product is low.

\section{Consumer Involvement as a Mediator}

Mittal and Lee (1989) defined involvement as a "mindset" that allows investigators to identify situational differences in the buying decisions. Involvement signifies the indelible attachment of an individual with a particular brand or product category, which is evident through one's ample information search, brand awareness, and finally through brand promise (Houston \& Rothschild, 1978; Rothschild, 1979; Richins \& Bloch, 1986). According to Mittal \& Lee, (1989), situational involvement conditions are considered as low involvement conditions, wherein a consumer gets involved with a "situation," typically a buying decision.

A person analyses plausibly and logically about information stimuli in case of high involvement purchase situations using a central route to persuasion. Whereas, he uses peripheral route of persuasion for products which need low involvement and less cognitive efforts (Wang et al., 2019). While Jain et al. (2010) posits considerable impact of individuals' attitude towards the brand for high involvement products. Many studies affirmed that level of consumer involvement play a vital role in influencing the endorser-brand congruence (Bower \& Landreth, 2001; Lee \& Thorson, 2008). Physically attractive celebrities are perceived to be reliable and thus, encourage positive attitude of the consumers towards a brand, which influence its involvement (Ohanian, 1991). Therefore in this paper we also proposed to test the mediating role of consumer involvement in explaining the relationship between independent variables and the dependent variables.

\section{Attitude toward advertisement, brand, and purchase intention}

Persuasion aspect in celebrity endorsement studies has primary focus on the consumer's attitudinal shift in favour of the advertisement, brand, and purchase intentions. Attitude is considered to be relatively enduring, purposeful, gradual, exhaustive, and motivated buyers' intent to respond to a specific object (Banyte et al., 2007). Thus, it can be inferred that attitude could be molded toward a particular brand of a firm which can be understood as "brand attitude" or attitude towards the brand. This can be defined as a buyers' overall evaluation of a brand. Lutz (1985) defined attitude towards the advertisement as thought predisposition of reaction 
(favourable or unfavourable) on the basis of shown advertisements. Purchase intentions have been deliberated by marketing managers very commonly to take decision about the products or services they offer for sale. Purchase intentions can be understood as the willingness or intention of a customer to buy a certain product or a service. Use of a celebrity in endorsing a brand favourably affects the consumers' attitude towards brand and purchase intention (Kamins, 1990). Celebrities engaged by marketers to lend their persona to a brand have been found to produce more positive responses toward ad and better buying intentions than a noncelebrity endorser (Atkin \& Block, 1983). According to Singh and Banerjee (2018), celebrity trustworthiness has a significant influence on consumers' attitude towards the brand, advertisement, and purchase intention.

\section{Proposed Framework}

The present study therefore focuses on understanding the impact of celebrity endorsement on consumers' attitude towards the advertisement, towards the brand, and buying intentions. This research in addition, explores the mediating effect of consumer involvement between the predictor variables (celebrity attractiveness and celebrity-product congruence) and the three output factors. Thus, the research intends to develop a comprehensive framework using celebrity endorsement, consumer involvement (high and low involvement product), and the resultant formation (or otherwise) of attitude towards the advertisement and the brand therein, and purchase intention (refer to Figure 1).

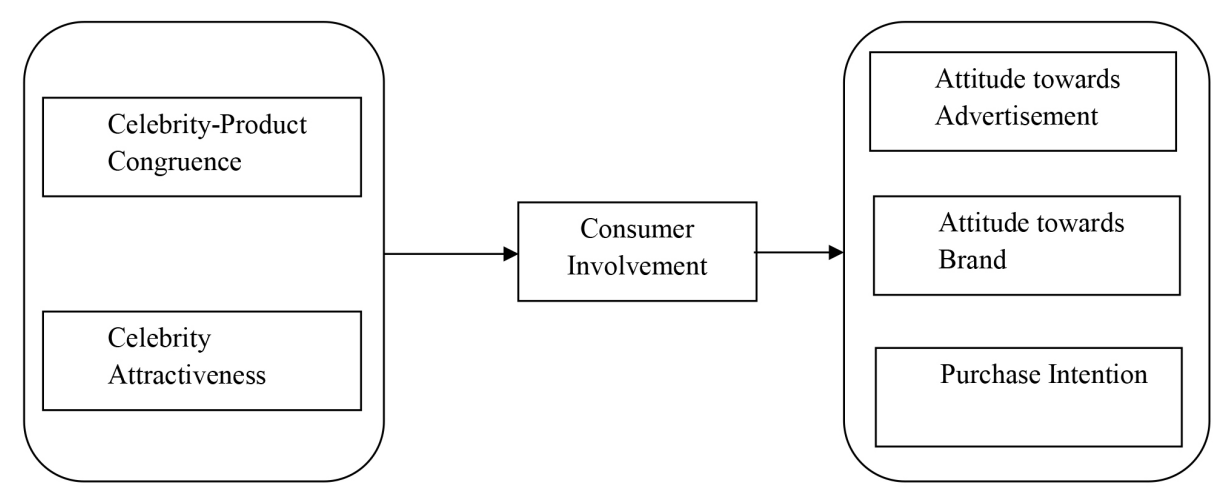

Figure 1. Proposed framework 


\section{Hypotheses Development}

The argument leading this study is "celebrity-product fitment augments the effectiveness of advertisement that features celebrity, and has a bigger impact on the consumer's attitude and intention." Hence, the research focuses on developing a comprehensive model framework of celebrity endorsement grounded on similarity amid the celebrity endorsing the product and the product itself, and attractiveness of celebrity. Here is the brief description of postulations that form the part of proposed theoretical framework.

\section{Celebrity-Product Congruence and Consumer Involvement}

According to Lee and Thorson (2008), even though there exists hardly any reservation that a congruence between a product and a celebrity can increase the efficacy of any marketing promotional cue, the question remains, "which is more influential between a fit and a disparity?" It was observed that there is a tendency to favourably evaluate celebrity endorsements in terms of buying intentions, in a situation with a moderate disparity between a product and a celebrity, as against the situation of a complete congruence or an extreme disparity. Also, such impacts are more prominent among consumers with a higher level of product involvement than those with lesser product involvement. Involvement levels play an important role in influencing the celebrity endorser-product congruence (Bower \& Landreth, 2001; Lee \& Thorson, 2008; Till \& Busler, 2000) and in endorser-credibility effect on consumer responses (Goldsmith et al., 2000; Lafferty \& Goldsmith, 1999, 2004; Ferle \& Choi, 2005). Roozen and Claeys (2010) also supported the importance of classifying the high and low involvement products in analysing the endorser effects. Handriana and Wisandiko (2017) also posited that the number of endorsers and the consumer's involvement into the product affect their attitude towards the brand and the advertisement. They reiterated that strategy of using multiple endorsers in case of low involvement would help generate better consumers' attitude towards the brand than a single celebrity endorsement. Similar outcome was also found by McAlister and Bargh (2016).

Based on the above discussions regarding the celebrity-product congruence and consumer involvement, following hypotheses are postulated for two sets of products, i.e., for Vivo (high involvement product) and Lux (low involvement product):

$\mathrm{H}_{1 \mathrm{a}}$ : There will be a positive relationship between celebrity-product congruence and consumer involvement for high involvement product 
$\mathrm{H}_{1 \mathrm{~b}}$ : There will be a positive relationship between celebrity-product congruence and consumer involvement for low involvement product

\section{Celebrity Attractiveness and Consumer Involvement}

As per Ohanian (1991), attractiveness is determined by whether a celebrity appears to be physically good looking to the consumers. Celebrities perceived to be knowledgeable, honest, and physically good looking are perceived to be trustworthy and thus, encourage positive attitudinal and behavioural reactions of the consumers (Ohanian, 1991). As per Arora et al. (2019), celebrity attractiveness has a favourable impact on consumers' purchase intentions whereas celebrity congruence and consumer involvement have insignificant influence on purchase intention. The congeniality factor that transforms into a more positive attitude toward the brand augments the shopper's connection with the brand and signifies a direct association to purchase intention (Praxmarer, 2009). Celebrities are frequently engaged by marketers to lend their persona to a brand (Kaikati, 1987). As aforestated, celebrity is perceived as a well-informed, experienced and trustworthy person, who enhances the credibility of information provided in advertisement therefore impacting the central path. On the other side, celebrity attractiveness influences the peripheral route of the brain. Therefore, both central and peripheral route are used for decision making (Wang et al., 2019). Atkin and Block (1983), and Petty et al. (1983) research reveals that celebrities generate more positive responses toward advertisements and higher purchase intentions, and may reduce involvement as against a non-celebrity or a normal endorser. Therefore, following hypotheses are formulated:

$\mathrm{H}_{2 \mathrm{a}}$ : There will be a negative relationship between celebrity attractiveness and consumer involvement for high involvement product

$\mathrm{H}_{2 b}$ : There will be a negative relationship between celebrity attractiveness and consumer involvement for low involvement product

\section{Consumer Involvement and Attitude Towards Advertisement}

According to Rubin and Perse (1987), para-social relations are high-reward/lowcost exchanges when the celebrity is attractive, and the fans control one-way affiliation. Meanwhile, there is increasing substantiation that para-social relations involve both calculative and affective commitments that emerges from a consumer's strong emotive connection with the celebrity. Handriana and Wisandiko (2017) also posited that consumer's involvement affect their attitude towards the brand and the advertisement. The impact of the consumers' level of involvement on their 
attitude towards the advertisement has not been studied much in earlier studies. Thus, the following hypotheses are formulated:

$\mathrm{H}_{3 \mathrm{a}}$ : There will be a positive relationship between consumer involvement and attitude towards advertisement for high involvement product

$\mathrm{H}_{3 \mathrm{~b}}$ : There will be a positive relationship between consumer involvement and attitude towards advertisement for low involvement product

\section{Consumer Involvement and Attitude Towards Brand}

Investigating the difference in effects of hiring a national and regional celebrity in case of low and high involvement products, Jain et al. (2010) noted significant consumers' attitude towards the brand for high involvement products. As per Bower and Landreth (2001), Lee and Thorson (2008), Till and Busler (2000), and Handriana and Wisandiko (2017), the levels of product involvement play an important role in the impact of endorser-product congruence on shoppers' response. It also plays a significant role in the endorser-credibility effect on consumer responses (Goldsmith et al., 2000; Lafferty \& Goldsmith, 1999, 2004; Ferle \& Choi, 2005). Thus, the next set of hypotheses is formulated to test the relationship between consumer involvement and the consumer attitude towards the brand for both high involvements as well as for low involvement products.

$\mathrm{H}_{4 \mathrm{a}}$ : There will be a positive relationship between consumer involvement and attitude towards brand for high involvement product

$\mathrm{H}_{4 \mathrm{~b}}$ : There will be a positive relationship between consumer involvement and attitude towards brand for low involvement product

\section{Consumer Involvement and Attitude Towards Purchase Intention}

Studies like Kahle et al. (1980) and Kahle and Timmer (1983) have revealed the inverse relationship between consumer's involvement in the product and the strength of the celebrity's influence on purchasing decision. Thus, higher involvement of a consumer leads to lesser celebrity's impact on purchase decision. The interaction effect of endorsement strength and celebrity-product congruence is more prominent when consumers are highly involved as against the ones with less involvement (Park et al., 2014). To understanding the impact of consumer involvement on their purchase intentions, following hypotheses were formulated:

$\mathrm{H}_{5 \mathrm{a}}$ : There will be a positive relationship between consumer involvement and attitude towards purchase intention for high involvement product 
$\mathrm{H}_{5 \mathrm{~b}}$ : There will be a positive relationship between consumer involvement and attitude towards purchase intention for low involvement product

From the discussion, the two hypothesised models are being proposed.

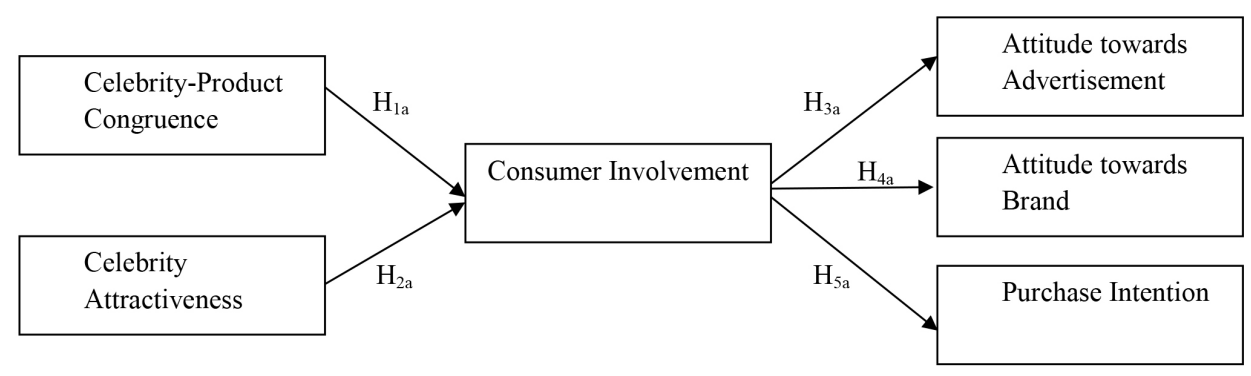

(a)

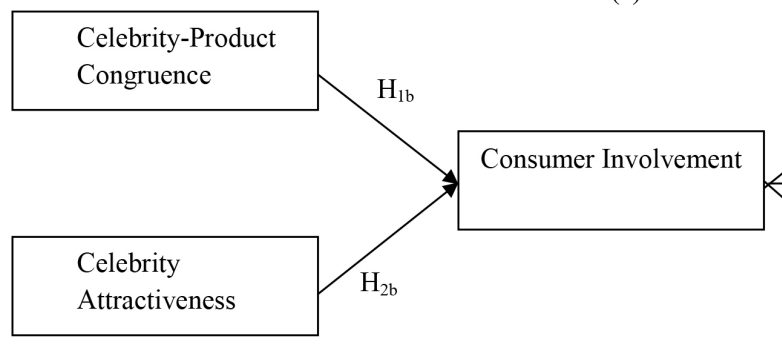

(b)

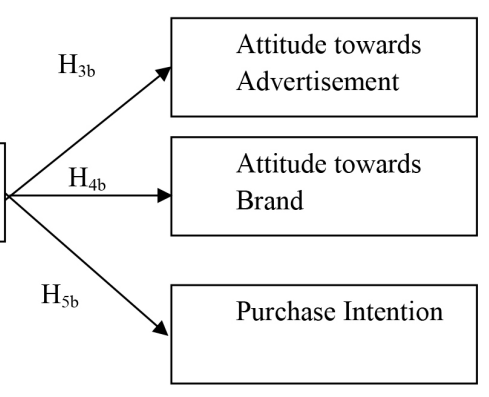

Attitude towards

Brand

Purchase Intention

Figure 2. Illustrations of (a) high involvement product, and (b) low involvement product

\section{RESEARCH METHODOLOGY}

\section{Study Frame}

It was decided to choose two products - Lux, India's leading brand of beauty soap, and Vivo, a rapid growing brand of smartphone in India. The brands were chosen based on their acceptance in Indian context. The former (soap brand) is a low involvement, while the latter (smartphone) is a high involvement product. Prices and celebrities endorsing the two products were the main criteria for choosing them to comprehend the role of consumers' involvement in the formation of their attitude towards advertisement, brand, and purchase intention. 


\section{Construction of Instrument}

The responses were collected using a structured questionnaire that was framed based on the validated scales from the previous studies. The scale from Lee and Koo (2015) was used for measuring celebrity-product congruence. To assess celebrity attractiveness, the scale of Ohanian (1990) was adopted. Consumer involvement was measured using the eight-item scale developed by Zaichkowsky (1985). The three-item scale from Ahmed et al. (2016) was adopted to measure attitude towards the two brands. Similarly, attitude towards the advertisement was assessed using the scale from Lichtle (2007). Finally, the purchase intention was measured using the scale developed by Chen and Teng (2013). These items were converted into statement and data was collected using a seven-point Likert's scale, where 1 and 7 represented "strongly disagree" and "strongly agree" respectively. The same instrument was used to test the hypothesised models for the two categories of products, being endorsed by two different celebrities from the entertainment industry in India. This instrument was pre-tested with a sample of thirty respondents each for both a high and a low involvement product.

\section{Data Collection}

The respondents from six prominent Indian cities were contacted at different locations and from different formats of retail outlets during April-July 2017 using mall-intercept method. Further, days and timing of data collection were varied to reduce sampling bias. In all, 310 respondents agreed to participate. After removing semi-finished questionnaires, the data points from 246 respondents for each of the two categories were used for analysis. As per Hair et al. (2006), the sample size should be at least eight times the number of items used in the survey instrument.

\section{Checking for Common Method Bias}

For measuring common method bias existed in the solution or not, Harman's post hoc one-factor analysis was conducted. Exploratory factor analysis disclosed that the maximum variance explained by a single factor was $20.31 \%$ only, which is less than $50 \%$. Hence, it is concluded that none of the single factor contributed for majority of the variance explained, reflecting the absence of such bias.

\section{Analysis}

Using AMOS 22.0, the data was analysed with structural equation modelling (SEM). A two-step approach as recommended by Anderson and Gerbing (1988) was used. Confirmatory factory analysis (CFA) was conducted to estimate 
the measurement model, followed by testing the structural model and research hypotheses. This approach allows the testing of significance for all pattern coefficients besides assessing fitness of structural model with the data. This approach also extends a framework to compare the functional model of interest with next most likely theoretical alternatives.

\section{RESULTS}

\section{Measurement Model}

The model consisted of two exogenous variables (celebrity-product congruence and celebrity attractiveness) and four endogenous variables (consumer involvement, attitude towards advertisement, attitude towards brand, and purchase intention). The five hypotheses proposed for each of the two different products (as shown in Figure 2) were tested. To test the robustness and validity of the factors, the model comprising of six constructs was subject to CFA. The results from the measurement model are shown in Tables 1 and 2 for high involvement and low involvement product respectively. These includes standardised factor loading, critical ratio, average variance extracted (AVE), and composite reliability.

Apart from measuring the reliability and validity of the constructs, various fit indices were measured to check for the suitability and fit of the data with the proposed model. The ratios of chi-square minimum to degree of freedom (CMIN/ DF) were 1.58 and 1.56 for high and low involvement product respectively. It is below the cut-off criterion of 3.00 (Hair et al., 2006), indicating a good fit between the data and the proposed model. Other fit indices - goodness-of-fit index (GFI), comparative fit index (CFI), incremental fit index (IFI), and Tucker-Lewis index (TLI) and root mean square error of approximation (RMSEA) were also assessed to further check for the fit between the data and the proposed model. As per Hair et al. (2006), while the first four should be greater than 0.9, RMSEA should be less than 0.08. From Tables 1 and 2 , all the fit indices values confirm the proposed model to have a good fit with the data. 
Table 1:

Descriptive statistics, reliability, and convergent validity (high involvement)

\begin{tabular}{|c|c|c|c|c|}
\hline & Items & $\begin{array}{l}\text { Standardised } \\
\text { loading } \\
\text { estimates }\end{array}$ & $\begin{array}{l}\text { AVE (rule } \\
\text { of thumb, } \\
\text { should } \\
\text { exceed } 0.5 \text { ) }\end{array}$ & $\begin{array}{l}\text { CR (rule } \\
\text { of thumb, } \\
\text { should } \\
\text { exceed } 0.7 \text { ) }\end{array}$ \\
\hline \multirow[t]{3}{*}{$\begin{array}{l}\text { Celebrity-product } \\
\text { congruence }\end{array}$} & $\begin{array}{l}\text { Celebrity-product } \\
\text { congruence } 3\end{array}$ & 0.894 & \multirow[t]{3}{*}{0.81} & \multirow[t]{3}{*}{0.93} \\
\hline & $\begin{array}{l}\text { Celebrity-product } \\
\text { congruence } 2\end{array}$ & 0.904 & & \\
\hline & $\begin{array}{l}\text { Celebrity-product } \\
\text { congruence } 1\end{array}$ & 0.897 & & \\
\hline \multirow{4}{*}{$\begin{array}{l}\text { Celebrity } \\
\text { attractiveness }\end{array}$} & Celebrity attractiveness 4 & 0.802 & \multirow[t]{4}{*}{0.68} & \multirow[t]{4}{*}{0.89} \\
\hline & Celebrity attractiveness 3 & 0.779 & & \\
\hline & Celebrity attractiveness 2 & 0.849 & & \\
\hline & Celebrity attractiveness 1 & 0.862 & & \\
\hline \multirow{8}{*}{$\begin{array}{l}\text { Consumer } \\
\text { involvement }\end{array}$} & Consumer involvement 8 & 0.645 & \multirow[t]{8}{*}{0.50} & \multirow[t]{8}{*}{0.89} \\
\hline & Consumer involvement 7 & 0.78 & & \\
\hline & Consumer involvement 6 & 0.671 & & \\
\hline & Consumer involvement 4 & 0.675 & & \\
\hline & Consumer involvement 3 & 0.782 & & \\
\hline & Consumer involvement 2 & 0.735 & & \\
\hline & Consumer involvement 1 & 0.684 & & \\
\hline & Consumer involvement 5 & 0.653 & & \\
\hline \multirow{4}{*}{$\begin{array}{l}\text { Attitude towards } \\
\text { ad }\end{array}$} & Attitude towards ad 1 & 0.858 & \multirow[t]{4}{*}{0.68} & \multirow[t]{4}{*}{0.83} \\
\hline & Attitude towards ad 2 & 0.865 & & \\
\hline & Attitude towards ad 3 & 0.808 & & \\
\hline & Attitude towards ad 4 & 0.754 & & \\
\hline \multirow{3}{*}{$\begin{array}{l}\text { Attitude towards } \\
\text { brand }\end{array}$} & Attitude towards brand 1 & 0.84 & \multirow[t]{3}{*}{0.70} & \multirow[t]{3}{*}{0.87} \\
\hline & Attitude towards brand 2 & 0.828 & & \\
\hline & Attitude towards brand 3 & 0.835 & & \\
\hline \multirow[t]{3}{*}{ Purchase intention } & Purchase intention 1 & 0.866 & \multirow[t]{3}{*}{0.69} & \multirow[t]{3}{*}{0.87} \\
\hline & Purchase intention 2 & 0.867 & & \\
\hline & Purchase intention 3 & 0.751 & & \\
\hline
\end{tabular}

$\mathrm{CMIN} / \mathrm{DF}=1.580 ; \mathrm{GFI}=0.873 ; \mathrm{CFI}=0.960 ; \mathrm{IFI}=0.961 ; \mathrm{TLI}=0.948 ; \mathrm{RMSEA}=0.055$ 
Table 2

Descriptive statistics, reliability, and convergent validity (low involvement)

\begin{tabular}{|c|c|c|c|c|}
\hline & Items & $\begin{array}{c}\text { Standardised loading } \\
\text { estimates }\end{array}$ & AVE & $\mathrm{CR}$ \\
\hline \multirow{3}{*}{$\begin{array}{l}\text { Celebrity- } \\
\text { product } \\
\text { congruence }\end{array}$} & $\begin{array}{l}\text { Celebrity-product } \\
\text { congruence } 3\end{array}$ & 0.889 & \multirow[t]{3}{*}{0.80} & \multirow[t]{3}{*}{0.92} \\
\hline & $\begin{array}{l}\text { Celebrity-product } \\
\text { congruence } 2\end{array}$ & 0.95 & & \\
\hline & $\begin{array}{l}\text { Celebrity-product } \\
\text { congruence } 1\end{array}$ & 0.842 & & \\
\hline \multirow{4}{*}{$\begin{array}{l}\text { Celebrity } \\
\text { attractiveness }\end{array}$} & Celebrity attractiveness 4 & 0.7 & \multirow[t]{4}{*}{0.60} & \multirow[t]{4}{*}{0.86} \\
\hline & Celebrity attractiveness 3 & 0.752 & & \\
\hline & Celebrity attractiveness 2 & 0.858 & & \\
\hline & Celebrity attractiveness 1 & 0.791 & & \\
\hline \multirow{8}{*}{$\begin{array}{l}\text { Consumer } \\
\text { involvement }\end{array}$} & Consumer involvement 8 & 0.677 & \multirow[t]{8}{*}{0.50} & \multirow[t]{8}{*}{0.89} \\
\hline & Consumer involvement 7 & 0.78 & & \\
\hline & Consumer involvement 6 & 0.725 & & \\
\hline & Consumer involvement 4 & 0.681 & & \\
\hline & Consumer involvement 3 & 0.728 & & \\
\hline & Consumer involvement 2 & 0.685 & & \\
\hline & Consumer involvement 1 & 0.721 & & \\
\hline & Consumer involvement 5 & 0.641 & & \\
\hline \multirow{4}{*}{$\begin{array}{l}\text { Attitude } \\
\text { towards ad }\end{array}$} & Attitude towards ad 1 & 0.886 & \multirow[t]{4}{*}{0.63} & \multirow[t]{4}{*}{0.79} \\
\hline & Attitude towards ad 2 & 0.802 & & \\
\hline & Attitude towards ad 3 & 0.674 & & \\
\hline & Attitude towards ad 4 & 0.794 & & \\
\hline \multirow{3}{*}{$\begin{array}{l}\text { Attitude } \\
\text { towards brand }\end{array}$} & Attitude towards brand 1 & 0.908 & \multirow[t]{3}{*}{0.79} & \multirow[t]{3}{*}{0.92} \\
\hline & Attitude towards brand 2 & 0.943 & & \\
\hline & Attitude towards brand 3 & 0.81 & & \\
\hline \multirow{3}{*}{$\begin{array}{l}\text { Purchase } \\
\text { intention }\end{array}$} & Purchase intention 1 & 0.903 & \multirow[t]{3}{*}{0.67} & \multirow[t]{3}{*}{0.86} \\
\hline & Purchase intention 2 & 0.827 & & \\
\hline & Purchase intention 3 & 0.708 & & \\
\hline
\end{tabular}




\section{Hypothesis Testing}

Once the measurement models were confirmed to be satisfactory, the assessment of the hypothesised structural model was undertaken using SEM with AMOS 22.0. The structural model's fit is determined using fit indices - GFI, AGFI, NFI, TLI, CFI, and RMSEA (Hair et al., 2006). The indices' values for the high involvement product $(\mathrm{GFI}=0.88, \mathrm{CFI}=0.95, \mathrm{IFI}=0.95, \mathrm{TLI}=0.94$, and $\mathrm{RMSEA}=0.06)$ reflect a good fit of the model with the data. The results of the hypothesised model are presented in Table 3. Similarly, for a low involvement product, all the indices reflect a good fit of the model with the data (see Table 4).

Table 3

Structural model results (high involvement)

\begin{tabular}{|c|c|c|c|c|c|}
\hline Hypothesis & & & $\mathrm{b}$ & $\mathrm{P}$ & Label \\
\hline $\begin{array}{l}\text { Celebrity-product } \\
\text { congruence }\end{array}$ & $\rightarrow$ & $\begin{array}{l}\text { Consumer } \\
\text { involvement }\end{array}$ & -0.188 & 0.055 & Not supported \\
\hline Celebrity attractiveness & $\rightarrow$ & $\begin{array}{l}\text { Consumer } \\
\text { involvement }\end{array}$ & -0.496 & 0.008 & Supported \\
\hline Consumer involvement & $\rightarrow$ & Attitude towards ad & 0.928 & 0.003 & Supported \\
\hline Consumer involvement & $\rightarrow$ & $\begin{array}{l}\text { Attitude towards } \\
\text { brand }\end{array}$ & 0.557 & 0.007 & Supported \\
\hline Consumer involvement & $\rightarrow$ & Purchase intention & 0.905 & 0.003 & Supported \\
\hline
\end{tabular}

$\mathrm{CMIN} / \mathrm{DF}=1.714 ; \mathrm{GFI}=0.884 ; \mathrm{CFI}=0.955 ; \mathrm{IFI}=0.956 ; \mathrm{TL} \mathrm{I}=0.935 ; \mathrm{RMSEA}=0.061$

Table 4

Structural model results (low involvement)

\begin{tabular}{llllll}
\hline Hypothesis & & & $\mathrm{b}$ & $\mathrm{P}$ & Label \\
\hline $\begin{array}{l}\text { Celebrity-product } \\
\text { congruence } \\
\text { Celebrity attractiveness }\end{array}$ & $\rightarrow$ & $\begin{array}{l}\text { Consumer } \\
\text { involvement }\end{array}$ & 0.121 & 0.091 & Not supported \\
Consumer involvement & $\rightarrow$ & $\begin{array}{l}\text { Consumer } \\
\text { involvement }\end{array}$ & -0.496 & $* * *$ & Supported \\
Consumer involvement & $\rightarrow$ & $\begin{array}{l}\text { Attitude towards } \\
\text { ad }\end{array}$ & 0.993 & $* * *$ & Attitude towards \\
brand & 0.406 & $* * *$ & Supported \\
Consumer involvement & $\rightarrow$ & $\begin{array}{l}\text { Purchase intention } \\
\text { CMIN/DF }=1.498 ; \text { GFI }=0.875 ;\end{array}$ & 0.915 & $* * *$ & CFI $=0.955 ;$ IFI $=0.966 ;$ TLI $=0.953 ;$ RMSEA $=0.053$
\end{tabular}


The association between celebrity-product congruence and consumer involvement was found to be insignificant for both high and low involvement products $(\beta=-0.188, p=0.055 ; \beta=0.121, p=0.091)$. Hence, the two hypotheses $\mathrm{H}_{1 \mathrm{a}}$ and $\mathrm{H}_{1 \mathrm{~b}}$ were rejected. With $\beta=-0.496, p=0.008$ and $\beta=-0.496, p=0.000$ for high and low involvement products respectively, celebrity attractiveness was found to have impact on consumer involvement in both the categories. Thus, the two hypotheses $\mathrm{H}_{2 \mathrm{a}}$ and $\mathrm{H}_{2 \mathrm{~b}}$ supported the negative relationship between celebrity attractiveness and consumer involvement for both high and low involvement product.

For a high involvement product category, the findings showed a significant impact of consumer involvement on attitude towards advertisement $(\beta=0.928, p<0.05)$, attitude towards brand $(\beta=0.557, \mathrm{p}<0.000)$ and purchase intention $(\beta=0.905$, $\mathrm{p}<0.000$ ). Hence, hypotheses $\mathrm{H}_{3 \mathrm{a}}, \mathrm{H}_{4 \mathrm{a}}$ and $\mathrm{H}_{5 \mathrm{a}}$ were accepted. Similarly, for low involvement products too (Table 4), it is noted that consumer involvement had a significant impact on the attitude towards advertisement, attitude towards brand, and purchase intention, supporting hypotheses $\mathrm{H}_{3 \mathrm{~b}}, \mathrm{H}_{4 \mathrm{~b}}$, and $\mathrm{H}_{5 \mathrm{~b}}$.

\section{Mediation Analysis}

To test the mediating role of consumer involvement for both high and low involvement products, Sobel test was conducted. From Table 5, it is observed that consumer involvement does not act as a mediator between celebrity productcongruence and attitude towards advertisement, brand and purchase intention for both the category of product. However, consumer involvement has been noted to act as a mediator between celebrity attractiveness and the three dimensions of consumer evaluation.

Table 5

Mediation analysis

\begin{tabular}{|c|c|c|c|c|c|c|c|c|}
\hline \multicolumn{5}{|c|}{ Low involvement } & \multirow{2}{*}{$\begin{array}{l}\begin{array}{l}\text { Test } \\
\text { statistic }\end{array} \\
0.49\end{array}$} & \multirow{2}{*}{$\begin{array}{l}\begin{array}{l}\text { Std. } \\
\text { error }\end{array} \\
0.13\end{array}$} & \multirow{2}{*}{$\begin{array}{l}P \\
0.63\end{array}$} & \multirow{2}{*}{$\begin{array}{l}\text { Result } \\
\text { Not } \\
\text { supported }\end{array}$} \\
\hline $\begin{array}{l}\text { Celebrity- } \\
\text { product } \\
\text { congruence }\end{array}$ & $\rightarrow$ & $\begin{array}{l}\text { Consumer } \\
\text { involvement }\end{array}$ & $\rightarrow$ & $\begin{array}{l}\text { Attitude } \\
\text { towards ad }\end{array}$ & & & & \\
\hline $\begin{array}{l}\text { Celebrity- } \\
\text { product } \\
\text { congruence }\end{array}$ & $\rightarrow$ & $\begin{array}{l}\text { Consumer } \\
\text { involvement }\end{array}$ & $\rightarrow$ & $\begin{array}{l}\text { Attitude } \\
\text { towards brand }\end{array}$ & 0.49 & 0.088 & 0.63 & $\begin{array}{l}\text { Not } \\
\text { supported }\end{array}$ \\
\hline $\begin{array}{l}\text { Celebrity- } \\
\text { product } \\
\text { congruence }\end{array}$ & $\rightarrow$ & $\begin{array}{l}\text { Consumer } \\
\text { involvement }\end{array}$ & $\rightarrow$ & $\begin{array}{l}\text { Purchase } \\
\text { intention }\end{array}$ & 0.48 & 0.12 & 0.62 & $\begin{array}{l}\text { Not } \\
\text { supported }\end{array}$ \\
\hline
\end{tabular}

(continued on next page) 
Table 5: (continued)

\begin{tabular}{|c|c|c|c|c|c|c|c|c|}
\hline \multicolumn{5}{|c|}{ Low involvement } & \multirow{2}{*}{$\begin{array}{l}\text { Test } \\
\text { statistic } \\
2.062\end{array}$} & \multirow{2}{*}{$\begin{array}{l}\begin{array}{l}\text { Std. } \\
\text { error }\end{array} \\
0.036\end{array}$} & \multirow{2}{*}{$\begin{array}{l}P \\
0.039\end{array}$} & \multirow{2}{*}{$\begin{array}{l}\text { Result } \\
\text { Supported }\end{array}$} \\
\hline $\begin{array}{l}\text { Celebrity } \\
\text { attractiveness }\end{array}$ & $\rightarrow$ & $\begin{array}{l}\text { Consumer } \\
\text { involvement }\end{array}$ & $\rightarrow$ & $\begin{array}{l}\text { Attitude } \\
\text { towards ad }\end{array}$ & & & & \\
\hline $\begin{array}{l}\text { Celebrity } \\
\text { attractiveness }\end{array}$ & $\rightarrow$ & $\begin{array}{l}\text { Consumer } \\
\text { involvement }\end{array}$ & $\rightarrow$ & $\begin{array}{l}\text { Attitude } \\
\text { towards brand }\end{array}$ & 1.96 & 0.024 & 0.49 & Supported \\
\hline $\begin{array}{l}\text { Celebrity } \\
\text { attractiveness }\end{array}$ & $\rightarrow$ & $\begin{array}{l}\text { Consumer } \\
\text { involvement }\end{array}$ & $\rightarrow$ & $\begin{array}{l}\text { Purchase } \\
\text { intention }\end{array}$ & 2.024 & 0.032 & 0.043 & Supported \\
\hline High involvem & ent & & & & $\begin{array}{l}\text { Test } \\
\text { statistic }\end{array}$ & $\begin{array}{l}\text { Std. } \\
\text { error }\end{array}$ & $\mathrm{P}$ & Result \\
\hline $\begin{array}{l}\text { Celebrity- } \\
\text { product } \\
\text { congruence }\end{array}$ & $\rightarrow$ & $\begin{array}{l}\text { Consumer } \\
\text { involvement }\end{array}$ & $\rightarrow$ & $\begin{array}{l}\text { Attitude } \\
\text { towards ad }\end{array}$ & 0.423 & .016 & 0.67 & $\begin{array}{l}\text { Not } \\
\text { supported }\end{array}$ \\
\hline $\begin{array}{l}\text { Celebrity- } \\
\text { product } \\
\text { congruence }\end{array}$ & $\rightarrow$ & $\begin{array}{l}\text { Consumer } \\
\text { involvement }\end{array}$ & $\rightarrow$ & $\begin{array}{l}\text { Attitude } \\
\text { towards brand }\end{array}$ & 0.42 & 0.01 & 0.67 & $\begin{array}{l}\text { Not } \\
\text { supported }\end{array}$ \\
\hline $\begin{array}{l}\text { Celebrity- } \\
\text { product } \\
\text { congruence }\end{array}$ & $\rightarrow$ & $\begin{array}{l}\text { Consumer } \\
\text { involvement }\end{array}$ & $\rightarrow$ & $\begin{array}{l}\text { Purchase } \\
\text { intention }\end{array}$ & 042 & 0.01 & 0.67 & $\begin{array}{l}\text { Not } \\
\text { supported }\end{array}$ \\
\hline $\begin{array}{l}\text { Celebrity } \\
\text { attractiveness }\end{array}$ & $\rightarrow$ & $\begin{array}{l}\text { Consumer } \\
\text { involvement }\end{array}$ & $\rightarrow$ & $\begin{array}{l}\text { Attitude } \\
\text { towards ad }\end{array}$ & 2.10 & 0.06 & 0.027 & Supported \\
\hline $\begin{array}{l}\text { Celebrity } \\
\text { attractiveness }\end{array}$ & $\rightarrow$ & $\begin{array}{l}\text { Consumer } \\
\text { involvement }\end{array}$ & $\rightarrow$ & $\begin{array}{l}\text { Attitude } \\
\text { towards } \\
\text { Brand }\end{array}$ & 1.97 & 0.027 & 0.033 & Supported \\
\hline $\begin{array}{l}\text { Celebrity } \\
\text { attractiveness }\end{array}$ & $\rightarrow$ & $\begin{array}{l}\text { Consumer } \\
\text { involvement }\end{array}$ & $\rightarrow$ & $\begin{array}{l}\text { Purchase } \\
\text { intention }\end{array}$ & 2.64 & 0.021 & 0.09 & Supported \\
\hline
\end{tabular}

\section{DISCUSSION}

This research was primarily aimed to develop and test a conceptual model depicting the influence of celebrity endorsement on the consumers' attitude and purchase intention with a mediating effect of consumers' level of involvement. This examines the impact of the two constructs of celebrity endorsement - celebrityproduct congruence and celebrity attractiveness, on consumers' attitude towards advertisement, attitude towards brand and purchase intention. The mediating role of consumer involvement has also been studied and compared for both a low as well as high involvement products. 
From the results obtained, the proposed model was observed to be a good fit with the collected data, and four out of five hypotheses in each case were supported. The hypothesis postulating the influence of celebrity-product congruence on consumer involvement was not supported in either of the two cases. This might be attributed to the fact that although the celebrity characteristics are consistent with the brand, the level of consumer involvement (Fleck et al., 2012; Misra \& Beatty, 1990) varies from individual to individual (MacKenzie \& Lutz, 1989).

In both the cases, celebrity attractiveness was found to have a significant but negative impact on the consumer involvement. This result is in line with a study by MacKenzie and Lutz (1989), which too have supported a relationship between these constructs. The negative value of the coefficient reflects that as the level of celebrity attractiveness increases, the level of consumer involvement decreases which is also in line with the ELM (Petty et al., 1983) which posits that consumers with low involvement are easily influenced by peripheral cues (celebrity) during information processing. This result provides an opportunity for marketers to attract more consumers by choosing an attractive celebrity, who has universal appeal. Such celebrities have similar impact on both low and high involvement products.

Furthermore, the research models also indicate the mediating influence of consumer involvement between the celebrity attractiveness (independent) variables and consumers' attitude towards advertisement, brand, and the purchase intention. This finding is in line with earlier studies of Bower and Landreth (2001) and Lee and Thorson (2008), which posited the influence of consumer's involvement with the product on his/her response.

The hypotheses $\left(\mathrm{H}_{3 \mathrm{a}}\right.$ and $\left.\mathrm{H}_{3 \mathrm{~b}}\right)$ reflecting the influence of consumer involvement on attitude towards advertisement, for both the high and low involvement product, were found to be statistically significant. Thus, consumer involvement has influence on attitude towards advertisements. This result reflects that consumer involvement helps in building shoppers' attitudes and purchase intentions, thereby supporting MacKenzie and Lutz (1989). Also, among the three resultant variables, it is observed that consumer involvement has the highest influence on attitude towards advertisements for both high $(\beta=0.928)$ and low $(\beta=0.993)$ involvement products. The higher $\beta$ value for low involvement product reflects that consumers rely more on advertisements for such products than for high involvement products. This can be attributed to the fact that high involvement products are usually high value products and are bought infrequently. Therefore, such decisions are irreversible and hence, consumers seek more information and assurance before buying products. 
With $\beta=0.557$ for a high involvement product, the association between the consumer involvement and attitude towards brand was found significant. Similarly, for a low involvement product $(\beta=0.406)$, this impact was also noted to be significant. From this, it can be inferred that the influence of consumer involvement on attitude towards brand is greater for high involvement products than a low involvement product category. This result is congruent with the findings by Jain et al. (2010).

The paper has also hypothesised the positive relationship between consumer involvement and purchase intention. A significant positive relationship was noted between the two constructs for both high and low involvement product categories respectively. This result also supports the findings of Park et al. (2014), which posited that the influence of a celebrity is greater when the consumer's involvement in the product is low and hence, purchase intention is more. This study cements the finds of Petty et al. (1983), which has observed that involvement plays a significant role in consumer motivation to purchase.

\section{Theoretical Implications}

The findings of the present study bring about some significant academic and managerial implications and add further strength to the studies on endorsement. First, prior studies in the domain of advertising and marketing have supported the effects of endorser-product fit on consumer responses with traditional measures of advertising. Most of these studies have primarily focused on the main effect of celebrity endorser-product fit, likability or attractiveness and endorser's credibility without considering the interaction effects of the level of consumer involvement. The present study, on the other hand, has confirmed all the hypotheses except one indicating the relationship among celebrity-product congruence and consumer involvement. Thus, there exists relationships between celebrity attractiveness and consumer involvement, and consumer involvement and the various measures of advertising effectiveness, i.e., attitude toward the advertisement, attitude toward the brand, and purchase intention. Thus, the current study suggests that consumer responses are maximised when consumer involvement mediates the relationship between celebrity attractiveness and consumer behavioural intentions. Also, the level of consumer involvement affects the dependent variables significantly. Though all the three dependent variables are affected by consumer involvement, in both the categories, but its influence on attitude towards the brand is more in case of a high involvement as against a low involvement product. On the contrary, the influence of involvement on attitude towards advertisement and purchase intention is more for low involvement products. 
Several experimental researches have confirmed that source attractiveness creates positive consumer responses. The present research finding complements the existing research of Caballero and Pride (1984) and Debevec and Kernan, (1984), where the effectiveness of a physically attractive source was supported with respect to changing consumers' attitudes. Similarly, this paper cements the findings of Petroshius and Crocker (1989), Petty and Cacioppo (1986) and Liu et al. (2007) that supported the significant positive effect of attractiveness on enhancing buying intention.

The noteworthy contribution of the study pertains to the consideration of consumer involvement as a major aspect of consumers' decision making in purchase decisions, as affected by celebrity endorsement. Involvement construct has not been studied much in the earlier research on celebrity endorsements. This study presents cues for upcoming research in this area. Though the celebrity-product congruence construct has been very well supported by earlier studies for purchase intentions, the current study could not support this relationship. This paper highlighted the role of celebrity attractiveness in impacting consumer involvement that leads to attitude towards advertisements, brand and purchase intention.

Thus, the research makes several contributions to the existing literature in the field of celebrity endorsement. This study fills the existing gap in the literature on endorsement studies by exploring the mediating role of consumer involvement in forming the consumers' intentions to buy a product, and how involvement affects the consumers' attitude towards an advertisement and the brand. This study proves the importance of consumers' involvement in purchase decision, and contributes to the literature by confirming the role of celebrity attractiveness as a significant factor influencing consumer involvement in the buying process.

\section{Managerial Implications}

The outcomes of the research present certain inferences useful for managers. Since the inferences have pertinence with the conditions in which the study was conducted, the same have the relevance particularly in Indian perspective, where attractiveness and involvement are big drivers of how people perceive celebrities. The research reveals that source attractiveness plays a major role in influencing consumers in India and affects the level of consumer involvement, which subsequently influences their attitude and indulgence in the brand as well as the advertisement and their purchase intention. The study proposes some useful tips for brand and communication managers aiming to develop their brand strategy, which involves hiring a celebrity to endorse the product. 
Earlier studies suggest that it is imperative for brand managers to consider the attractiveness of a celebrity as an important construct in making decisions while hiring a celebrity to endorse a brand. The present study, however, postulates a significant but contrary impact of the celebrity attractiveness on the level of consumer involvement for both low as well as high involvement products. Celebrities supposedly conversant, earnest, and good-looking are assumed to be convincing, and resultantly, endorse affirmative perceptual, and behavioural response (Ohanian, 1991). Thus, attractiveness counts as a key aspect for the choice of the celebrity for managers. According to Praxmarer (2009), the attractiveness aspect of the celebrity, decodes into a more encouraging attitude in favour of the brand, augments shoppers' recognition with the brand. This may be a sign of an unwavering association to purchase intention. Moreover, managers must give due importance to consumer involvement level for the products endorsed by an attractive celebrity for both low and high involvement products. The managers must craft the relevant brand strategies, by duly comprehending the impact of involvement on consumers' attitude towards the advertisement, towards the brand, and the purchase intention.

The study also posits that consumer involvement plays a decisive role in generating an attitudinal change of the consumer towards the advertisement, the brand, and the purchase intention. The results support this relationship for both the low as well as high involvement products. The findings thus implicate that the decision makers must take the involvement factor into consideration while deciding on to engage the endorser for the brand. Thus, managers may use this model as a base to decide on the identification of an endorser for promoting a brand for both the low as well as high involvement product.

\section{Limitations and Scope for Future Studies}

The present study has certain limitations that also generate scope for future research in celebrity endorsement. Being limited to Indian consumers, this research must be replicated to a wider range of markets (nations and consumers) with different cultural settings. This will enhance the study findings' endorsement. Also, the products chosen for the study were limited to Lux (as a low involvement brand) and Vivo (as a high involvement brand). Extending the work to various other categories of products, including services and events shall improve generalisability of the findings. The scope of attractiveness of the celebrity and consumer involvement shall be an area where future research can be conducted. Celebrity attractiveness may be studied with celebrity performance as a moderator for measuring the relationship with purchase intention. 


\section{REFERENCES}

Ad Age (2010). Celebrity endorsements still push product. Retrieved 10 January 2019 from https://adage.com/article/cmo-strategy/marketing-celebrity-endorsementspush-product/146023.

Ahmed, R., Beard, F., \& Yoon, D. (2016). Examining and extending advertising's dual mediation hypothesis to a branded mobile phone app. Journal of Interactive Advertising, 16(2), 133-144.

Amos, C., Holmes, G., \& Strutton, D. (2008). Exploring the relationship between celebrity endorser effects and advertising effectiveness. International Journal of Advertising, 27, 209-234.

Anderson, J., \& Gerbing, D.W. (1988). Structural equation modeling in practice: A review and recommended two-step approach. Psychological Bulletin, 103(3), 411-423. https://doi.org/10.1037/0033-2909.103.3.411

Atkin, C., \& Block, M. (1983). Effectiveness of celebrity endorsers. Journal of Advertising Research, 23, 57-61.

Arora, N., Prashar, S., Parsad, C., \& Tata, S.V. (2019). Influence of celebrity factors, consumer attitude and involvement on shoppers' purchase intention using hierarchical regression. Decision, 46(3), 179-195. https://doi.org/10.1007/ s40622-019-00208-7.

Balakrishnan, L., \& Kumar, C.S. (2011). Effect of celebrity-based advertisements on the purchase attitude of consumers towards durable products (a study with reference to the city of Chennai). World Review of Business Research, 1(2), 98-112.

Banyte, J., Joksaite, E., \& Virvilaite, R. (2007). Relationship of consumer attitude and brand: Emotional aspect. Engineering Economics, 2(2), 65-77.

Belch, G.E., \& Belch, M.A. (2001). Advertising and promotion: An integrated marketing communications perspective. New York: McGraw-Hill.

Bhattacherjee, A., \& Sanford, C. (2006). Influence processes for information technology acceptance: An elaboration likelihood model. MIS Quarterly, 30(4), 805-825.

Bower, A.B., \& Landreth, S. (2001). Is beauty best? Highly versus normally attractive models in advertising. Journal of Advertising, 30, 1-12.

Bradic, L. (2015). Celebrity endorsements on social media are driving sales and winning over fans. Social Media Week. Retrieved 30 January 2019 from https:// socialmediaweek.org/blog/2015/09/brands-using-celebrity-endorsements/.

Branchik, B.J., \& Chowdhury, T.G. (2017). Men seeing stars: Celebrity endorsers, race, and the male consumer. Journal of Marketing Theory and Practice, 25(3), 305322.

Byrne, A., Whitehead, M., \& Breen, S. (2003). The naked truth of celebrity endorsement. British Food Journal, 105(4-5), 288-296.

Caballero, M.J., \& Pride, W.M. (1984). Selected effects of salesperson sex and attractiveness in direct mail advertisements. Journal of Marketing, 48(1), 94-100.

Chen, M.Y., \& Teng, C.I. (2013). A comprehensive model of the effects of online store image on purchase intention in an e-commerce environment. Electronic Commerce Research, 13, 1-23. 
Debevec, K., \& Kernan, J.B. (1984). More evidence on the effects of a presenter's attractiveness: Some cognitive, affective, and behavioral consequences. Advances in Consumer Research, 11, 127-132.

Dyson, A. \& Turco, D. (1998). The state of celebrity endorsement in sport. Cyber Journal of Sport Marketing, 2(1), 9-21.

Erdogan, Z.B. (1999). Celebrity endorsement: A literature review. Journal of Marketing Management, 15, 291-314.

Erdogan, Z.B., Baker, M.J., \& Tagg, S. (2001). Selecting celebrity endorsers: The practitioner's perspective. Journal of Advertising Research, 41(3), 39-48.

Ferle, C.L., \& Choi, S.M. (2005). The importance of perceived endorser credibility in South Korean advertising. Journal of Current Issues \& Research in Advertising, 27, 67-81.

Fleck, N., \& Quester, P. (2007). Birds of a feather flock together... Definition, role and measure of congruence: An application to sponsorship. Psychology \& Marketing, 24, 975-1000.

Fleck, N., Korchia, M., \& Roy, I.L. (2012). Celebrities in advertising: Looking for congruence or likability? Psychology and Marketing, 29, 651-662.

Flynn, B.S., Worden, J.K., Bunn, J.Y., Connolly, S.W., \& Dorwaldt, A.L. (2011). Evaluation of smoking prevention television messages based on the elaboration likelihood model. Health Education Research, 26(6), 976-987, https://doi. org/10.1093/her/cyr082.

Freiden, J.B. (1984). Advertising spokesperson effects: An examination of endorser type and gender on two audiences. Journal of Advertising Research, 24(5), 33-41.

Goldsmith, R.E., Lafferty, B.A., \& Newell, S.J. (2000). The impact of corporate credibility and celebrity credibility on consumer reaction to advertisements and brands. Journal of Advertising, 29, 43-54.

Goldsmith, R.E., \& Emmert, J. (1991). Measuring product-category involvement: A multitrait-multi-method study. Journal of Business Research, 23(4), 363-371.

Hair, J.F.J., Black, W.C., Babin, B.J., Anderson, R.E., \& Tatham, R.L. (2006). Multivariate data analysis. London: Pearson.

Handriana, T., \& Wisandiko, W.R. (2017). Consumer attitudes toward advertisement and brand, based on the number of endorsers and product involvement: An experimental study. Gadjah Mada International Journal of Business, 19(3), 289306.

Houston, M.J., \& Rothschild, M.L. (1978). Conceptual and methodological perspectives on involvement. In H.K. Hunt, (Ed.), Advances in consumer research 5 (pp. 184187). Ann Arbor, MI: Association for Consumer Research.

Hung, K., Chan, K.W., \& Tse, C.H. (2011). Assessing celebrity endorsement effects in China. Journal of Advertising Research, 51(4), 608-623.

Hur, K., Kim, T.T., Karatepe, O.M., \& Lee, G. (2017). An exploration of the factors influencing social media continuance usage and information sharing intentions among Korean travellers. Tourism Management, 63(4), 170-178.

Jain, V., Roy, S., Kumar, A., \& Kabra, A. (2010). Differential effect of national vs. regional on consumer attitudes. Management \& Marketing, 5(4),121-135. 
Janssens, W., \& Pelsmacker, P.D. (2005). Consumer preferences for the marketing of ethically labeled coffee. International Marketing Review, 22, 512-530.

Kahle, L.R., \& Homer, P.M. (1985). Physical attractiveness of the celebrity endorser: A social adaptation perspective. Journal of Consumer Research, 11, 954-961.

Kahle, L.R., \& Timmer, S.G. (1983). A theory and a method for studying values. In L.R. Kahle (Ed.), Social values and social change: Adaptation to life in America (pp. 43-69). New York: Praeger.

Kahle, L.R., Klingel, D.M., \& Kulka, R.A. (1980). A longitudinal study of adolescents' attitude-behavior consistency. Public Opinion Quarterly, 45, 402-414.

Kaikati, J.G. (1987). Celebrity advertising: A review and synthesis. International Journal of Advertising, 6, 93-105.

Kamins, M.A. (1990). An investigation into the "match-up" hypothesis in celebrity advertising: When beauty may be only skin deep. Journal of Advertising, 19, 4-13.

Kamins, M.A., \& Gupta, K. (1994). Congruence between spokesperson and product type: A matchup hypothesis perspective. Psychology and Marketing, 2(6), 569-586.

Kirmani, A., \& Shiv, B. (1998). Effects of source congruity on brand attitudes and beliefs: The moderating role of issue relevant elaboration. Journal of Consumer Psychology, 7, 25-47.

Lafferty, B.A., \& Goldsmith, R.E. (1999). Corporate credibility's role in consumers' attitudes and purchase intentions when a high versus a low credibility endorser is used in the ad. Journal of Business Research, 44, 109-116.

Lafferty, B.A., \& Goldsmith, E.R. (2004). How influential are corporate credibility and endorser attractiveness when innovators react to advertisements for a new high technology product? Corporate Reputation Review, 7(1), 24-36.

Lee, J.G., \& Thorson, E. (2008). The impact of celebrity product incongruence on the effectiveness of product endorsement. Journal of Advertising Research, 48, 433449.

Lee, Y., \& Koo, J. (2015). Athlete endorsement, attitudes, and purchase intention: The interaction effect between athlete endorser-product congruence and endorser credibility. Journal of Sport Management, 29, 523-538.

Lichtle, M.C. (2007). The effect of an advertisement's colour on emotions evoked by attitude towards the ad. International Journal of Advertising, 21, 37-62.

Liu, M.T., Huang, Y.Y., \& Minghua, F. (2007). Relations among attractiveness of endorsers, match-up, and purchase intention in sport marketing in China. Journal of Consumer Marketing, 24, 358-365.

Lutz, R.J. (1985). Affective and cognitive antecedents of attitude towards ad: A conceptual framework. In L.F. Alwitt, \& A.A. Mitchell (Eds.), Psychological processes and advertising effects: Theory, research and applications (pp. 45-63). Hillsdale, NJ: Lawrence Erlbaum Associates.

Lynch, J., \& Schuler, D. (1994). The match-up effect of spokesperson and product congruency: A schema theory interpretation. Psychology \& Marketing, 11, 417445. 
MacInnis, D.J., Moorman, C., \& Jaworski, B.J. (1991). Enhancing and measuring consumers' motivation, opportunity, and ability to process brand information from ads. Journal of Marketing, 55, 32-53.

Mowen, J.C. (1995). Consumer behavior, 4th ed. New Jersey: Prentice-Hall.

McCormick, K. (2016). Celebrity endorsements: Influence of a product-endorser match on Millennials attitudes and purchase intentions. Journal of Retailing and Consumer Services, 32, 39-45.

McCracken, G. (1989). Who is the celebrity endorser? Cultural foundations of the endorsement process. Journal of Consumer Research, 16, 310-321.

McGuire, W.J. (1985). Attitudes and attitude change. In L. Gardner, \& E. Aronson (Eds.), Handbook of social psychology (pp. 233-346). New York: Random House.

MacKenzie, S.B., \& Lutz, R.J. (1989). An empirical examination of the structural antecedents of attitude toward the ad in an advertising pretesting context. Journal of Marketing, 53, 48-65.

McAlister, A.R., \& Bargh, D. (2016). Dissuasion: The elaboration likelihood model and young children. Young Consumers, 17(3), 210-225. https://doi.org/10.1108/YC02-2016-00580

Misra, S., \& Beatty, S.E. (1990). Celebrity spokesperson and brand congruence: An assessment of recall and affect. Journal of Business Research, 21, 159-173.

Mishra, A.S., Roy, S., \& Bailey, A.A. (2015). Exploring brand personality-celebrity endorser personality congruence in celebrity endorsements in the Indian context. Psychology \& Marketing, 32(12), 1158-1174.

Mittal, B., \& Lee, M.S. (1989). A causal model of consumer involvement. Journal of Economic Psychology, 10(2), 363-389.

Munnukka, J., Uusitalo, O., \& Toivonen, H. (2016). Credibility of a peer endorser and advertising effectiveness. Journal of Consumer Marketing, 33(3), 182-192. https://doi.org/10.1108/JCM-11- 2014-1221

O’Guinn, T.C., Faber, R.J., Curias, N.J.S., \& Schmitt, K. (1989). The cultivation of consumer norms. In T.K. Srull (Ed.), Advances in consumer research (pp. 779785). Provo, UT: Association for Consumer Research.

Ohanian, R. (1990). Construction and validation of a scale to measure celebrity endorsers' perceived expertise, trustworthiness and attractiveness. Journal of Advertising, $19,39-52$.

Ohanian, R. (1991). The impact of celebrity spokespersons' perceived image on consumers' intention to purchase. Journal of Advertising Research, 31, 46-54.

Park, J., Lee, H. \& Kim, C. (2014). Corporate social responsibilities, consumer trust and corporate reputation: South Korean consumers' perspectives. Journal of Business Research, 67, 295-302.

Petroshius, S.M., \& Crocker, K.E. (1989). An empirical analysis of spokesperson characteristics on advertisement and product evaluations. Journal of the Academy of Marketing Science, 17, 217-225.

Petty, R.E., \& Cacioppo, J.T. (1986). Communication and persuasion: Central and peripheral routes to attitude change. New York: Springer-Verlag. 
Petty, R.E., Cacioppo, J.T., \& Schumann, D. (1983). Central and peripheral routes to advertising effectiveness: The moderating role of involvement. Journal of Consumer Research, 10(2), 135-146.

Pradhan, D., Duraipandian, I., \& Sethi, D. (2016). Celebrity endorsement: How celebritybrand-user personality congruence affects brand attitude and purchase intention. Journal of Marketing Communications, 22(5), 456-473. https://doi.org/10.1080/ 13527266.2014 .914561

Praxmarer, S. (2009). How does the presenter's physical attractiveness persuade? A test of alternative explanations. Proceedings of the Australian and New Zealand Marketing Academy Conference, (pp. 1-7), Melbourne.

Richins, M.L., \& Bloch, P.H. (1986). After the new wears off: The temporal context of product involvement. Journal of Consumer Research, 3, 280-285.

Roozen I., \& Claeys C. (2010). The relative effectiveness of celebrity endorsement for print advertisement. Review of Business and Economics, 1(1),76-89.

Rothschild, M.L. (1979). Advertising strategies for high and low involvement situations. In J.C. Maloney, \& B. Silverman (Eds.), Attitude research plays for high stakes (pp. 74-93). New York: American Marketing Association Proceedings.

Rubin, R.B., \& Perse, E.M. (1987). Audience activity and soap opera involvement: A uses and effects investigation. Human Communication Research, 14, 246-268.

Schaefer, A., \& Keillor, B. (1997). The effective use of endorsements in advertising: The relationship between "match-up" and involvement. Journal of Marketing Management, 7(2), 22-33.

Schenk, C.T., \& Holman, R.H. (1980). A sociological approach to brand choice: The concept of situational self image. In. J.C. Olson (Ed.), Advances in consumer research (pp. 610-614). Ann Arbor, MI: Association for Consumer Research.

Seno, D., \& Lukas A.B. (2007). The equity effect of product endorsement by celebrities: A conceptual framework from a co-branding perspective. European Journal of Marketing, 41(1/2), 121-134.

Singh, R.P., \& Banerjee, N. (2018). A study on exploring the factors influencing celebrity endorsement credibility. Global Business Review, 19(2), 494-509.

Sonwalkar, J., Kapse, M., \& Pathak, A. (2011). Celebrity impact: A model of celebrity endorsement. Journal of Marketing Communication, 7(1), 34-41.

Srivastava, K., \& Sharma, N.K. (2016). Consumer perception of brand personality: An empirical evidence from India. Global Business Review, 17(2), 375-388. https:// doi.org/10.1177/0972150915619814

Stern, B.B. (1988). Figurative language in services advertising: The nature and uses of imagery. In M.J. Houston (Ed.), Advances in consumer research (pp. 185-190). Provo, UT: Association for Consumer Research.

Till, B.D., \& Busler, M. (1998). Matching products with endorsers: Attractiveness versus expertise. Journal of Consumer Marketing, 15, 576-586.

Till, B.D., \& Busler, M. (2000). The match-up hypothesis: Physical attractiveness, expertise, and the role of fit on brand attitude, purchase intent and brand beliefs. Journal of Advertising, 29, 1-13. 
Wang, L., Fan, L., \& Bae, S. (2019). How to persuade an online gamer to give up cheating? Uniting elaboration likelihood model and signaling theory. Computers in Human Behavior, 96, 149-162.

Yang, W. (2018). Star power: The evolution of celebrity endorsement research. International Journal of Contemporary Hospitality Management, 30(1), 389-415.

Yang, S-F. (2015). An eye-tracking study of the Elaboration Likelihood Model in online shopping. Electronic Commerce Research and Applications, 14(4), 233-240.

Zaichkowsky, J.L. (1985). Measuring the involvement construct. Journal of Consumer Research, 12, 341-352.

Zhou, L., \& Whitla, P. (2013). How negative celebrity publicity influences consumer attitudes: The mediating role of moral reputation. Journal of Business Research, 66(8), 1013-1020. https://doi.org/10.1016/j.jbusres. 2011.12.025

\section{APPENDIX}

Measurement items of all of the studied constructs are as mentioned below:

1. Endorser product congruence (Lee \& Koo, 2015)

\begin{tabular}{lllllllll}
\hline Items & Scale & 1 & 2 & 3 & 4 & 5 & 6 & 7 \\
\hline Compatible / Not compatible & Lee \& Koo (2015) & & & & & & \\
A good fit / Not a good fit & Lee \& Koo (2015) & & & & & & \\
Congruent / Not congruent & Lee \& Koo (2015) & & & & & & \\
\hline
\end{tabular}

2. Endorser attractiveness (Ohanian, 1990)

\begin{tabular}{lllllllll}
\hline Items & Scale & 1 & 2 & 3 & 4 & 5 & 6 & 7 \\
\hline Classy-Not classy & Ohanian (1990) & & & & & & & \\
Attractive-Unattractive & Ohanian (1990) & & & & & & & \\
Beautiful-Ugly & Ohanian (1990) & & & & & & & \\
Elegant-Plain & Ohanian (1990) & & & & & & \\
Sexy-Not sexy & Ohanian (1990) & & & & & & \\
\hline
\end{tabular}

3. Consumer Involvement (Zaichkowsky, 1985)

\begin{tabular}{lllllllll}
\hline Items & Scale & 1 & 2 & 3 & 4 & 5 & 6 & 7 \\
\hline $\begin{array}{l}\text { I would be interested in reading } \\
\text { about various soaps available in } \\
\text { this price range }\end{array}$ & Zaichkowsky (1985) & & & & & & & \\
$\begin{array}{l}\text { I would read a consumer report/ } \\
\text { articles/ review about various soaps }\end{array}$ & Zaichkowsky (1985) & & & & & & \\
$\begin{array}{l}\text { I think there is great deal of } \\
\text { difference among various soap } \\
\text { brand }\end{array}$ & Zaichkowsky (1985) & & & & & & & \\
\hline
\end{tabular}




\begin{tabular}{|c|c|c|c|c|c|c|c|c|}
\hline Items & Scale & 1 & 2 & 3 & 4 & 5 & 6 & 7 \\
\hline $\begin{array}{l}\text { I have a most preferred soap brand } \\
\text { in my mind }\end{array}$ & Zaichkowsky (1985) & & & & & & & \\
\hline $\begin{array}{l}\text { I usually talk about this soap brand } \\
\text { with other people }\end{array}$ & Zaichkowsky (1985) & & & & & & & \\
\hline $\begin{array}{l}\text { I would seek advice from other } \\
\text { people prior purchasing soap }\end{array}$ & Zaichkowsky (1985) & & & & & & & \\
\hline $\begin{array}{l}\text { I usually consider many factors } \\
\text { before purchasing soap }\end{array}$ & Zaichkowsky (1985) & & & & & & & \\
\hline $\begin{array}{l}\text { I usually spend a lot of time before } \\
\text { choosing any products }\end{array}$ & Zaichkowsky (1985) & & & & & & & \\
\hline
\end{tabular}

4. Attitude towards the brand (Ahmed et al., 2016)

\begin{tabular}{lllllllll}
\hline Items & Scale & 1 & 2 & 3 & 4 & 5 & 6 & 7 \\
\hline Unfavourable / Favourable & Ahmed et al. (2016) & & & & & & & \\
Bad / Good & Ahmed et al. (2016) & & & & & & & \\
Negative / Positive & Ahmed et al. (2016) & & & & & & & \\
\hline
\end{tabular}

5. Attitude towards the ad (Lichtle, 2007)

\begin{tabular}{lllllllll}
\hline Items & Scale & 1 & 2 & 3 & 4 & 5 & 6 & 7 \\
\hline I find this ad convincing & Lichtle (2007) & & & & & \\
I find this ad intelligent & Lichtle (2007) & & & & & \\
It shows the product's qualities & Lichtle (2007) & & & & & \\
It is pleasant to look at & Lichtle (2007) & & & & & \\
It is informative & Lichtle (2007) & & & & & \\
\hline
\end{tabular}

6. Purchase intentions (Chen \& Teng, 2013)

\begin{tabular}{lllllllll}
\hline Items & Scale & 1 & 2 & 3 & 4 & 5 & 6 & 7 \\
\hline $\begin{array}{l}\text { I am positive towards buying the } \\
\text { travel products on the website }\end{array}$ & Chen \& Teng (2013) & & & & & & \\
$\begin{array}{l}\text { The thought of buying the travel } \\
\text { products at the website is appealing } \\
\text { to me }\end{array}$ & Chen \& Teng (2013) & & & & & & \\
$\begin{array}{l}\text { I think it is a good idea to buy the } \\
\text { travel products at the website }\end{array}$ & Chen \& Teng (2013) & & & & & & & \\
\end{tabular}

